\title{
Tygodniki opinii - użyteczny instrument marketingu politycznego?
}

\author{
Opinion-Forming Weeklies - A Useful Instrument \\ of Political Marketing?
}

\section{- Abstrakt •}

Celem badawczym artykułu jest próba ustalenia zakresu użyteczności marketingowej tygodników opinii z perspektywy aktorów politycznych. W kolejnych rozdziałach opracowania autor udziela odpowiedzi na cztery pytania uszczegóławiające: 1. Jakie funkcje w debacie publicznej pełnią tygodniki opinii o profilu społeczno-politycznym? 2. Czym charakteryzuje się marketing polityczny? 3. Jakimi instrumentami marketingowymi w warunkach pluralizmu światopoglądowego dysponują politycy? 4. Na czym polega użyteczność marketingowa tygodników opinii z punktu widzenia aktorów politycznych zabiegających o akredytację w oczach obywateli?

Słowa kluczowe: tygodniki opinii; marketing polityczny; debata publiczna

\section{- Abstract •}

The main objective of the article is an attempt to determine the marketing utility of opinionforming weeklies in the view of political actors. The following chapters include answers to questions, such as: 1 . What kind of functions in the political debate are fulfilled by opinionforming weeklies? 2. What distinctive features are related to the concept of political marketing? 3. What kind of marketing instruments remain at the disposal of politicians in pluralistic systems? 4. What is the significance of the marketing utility of opinion-forming weeklies in the view of political actors appealing for public support?

Keywords: opinion-forming weeklies; political marketing; public debate

\section{Wstęp}

Polską debatę publiczną - rozumianą w sposób możliwie szeroki - współtworzy ogromna, stale wzrastająca liczba aktorów życia społecznego. Wśród podmiotów biorących udział w wymianie informacji, ze względu na dysproporcje finansowo-organizacyjne, występują znaczne różnice w faktycznych możliwościach artykulacji swojego punktu widzenia. Poczynając od uprzywilejowanej pozycji skon- 
solidowanych aktorów politycznych, którzy posiadają wieloletnie doświadczenie współpracy z mediami; poprzez aktorów dopiero zabiegających o zdobycie rozgłosu (McQuail, 2011, s. 72-73)1 - aby móc w ogóle zaistnieć w świadomości opinii publicznej; poprzez rozmaite organizacje medialne, które nie tylko pośredniczą w masowej wymianie informacji, ale także dzierżą władzę nadawania symbolicznej rangi określonym wydarzeniom; i wreszcie... docierając do milionów aktywnych/ /biernych odbiorców treści poddawanych debacie. To o ich uwagę prowadzona jest informacyjna „walka o dusze” (Riedel, 2007, s. 15).

W tak zarysowanym kontekście jako cel badawczy artykułu określono próbę ustalenia zakresu użyteczności marketingowej tygodników opinii z perspektywy aktorów politycznych. Postawione zostały cztery uszczegóławiające pytania badawcze: 1. jakie funkcje w debacie publicznej pełnią tygodniki opinii o profilu społeczno-politycznym? 2. czym charakteryzuje się marketing polityczny? 3. jakimi instrumentami marketingowymi w warunkach pluralizmu światopoglądowego dysponują politycy? 4. na czym polega użyteczność marketingowa tygodników opinii z punktu widzenia aktorów politycznych zabiegających o akredytację w oczach obywateli? Kolejne rozdziały opracowania stanowią rozwinięcie powyższych kwestii problemowych.

\section{Funkcje tygodników opinii w polskiej debacie publicznej}

Sfera debaty publicznej stanowi podstawową, jawną przestrzeń wymiany informacji i komentarzy, w ramach której mamy do czynienia z równoległym istnieniem odmiennych wspólnot dyskursywnych. Na wielu poziomach komunikowania społecznego prowadzony jest dialog, występują spory, nieuchronnie następuje również konfrontacja odmiennych światopoglądów, ideologii i interesów. Agresywna szermierka słowna w programie publicystycznym lub umieszczenie barwnego fotomontażu na pierwszej stronie tabloidu gwarantują - co prawda - szerokie grono odbiorców i zysk dla wydawcy, aczkolwiek jednocześnie eliminują analityczny sposób argumentacji. W związku z tym Krzysztof Podemski wskazuje, iż to właśnie tygodniki opinii - ze względu na swój unikalny elitaryzm symboliczny - stanowią optymalną formę wyrażania dyskursu publicznego: „Z jednej strony

\footnotetext{
1 Publicity model of mass communication w rozumieniu Denisa McQuaila zakłada przede wszystkim, że ilościowe pojmowane zdobycie uwagi publiczności medialnej ma znaczenie o wiele większe, aniżeli faktyczne przyczyny uzyskania tejże uwagi oraz jej aspekty jakościowe. Fakt bycia znanym (rozpoznawalnym) w przestrzeni medialnej będzie w tym modelu kluczowy, leży bowiem u podstaw celebrytyzacji i tabloidyzacji współczesnego życia społeczno-politycznego.
} 
oddają one swoje łamy czołowym przedstawicielom elit symbolicznych, najlepszym publicystom i komentatorom, politycznym liderom, a często także wybitnym intelektualistom oraz uznanym ekspertom, także zagranicznym. Z drugiej - tygodniki opinii mają relatywnie dużą liczbę czytelników, docierają do setek tysięcy osób. Teksty z tygodników są cytowane i komentowane przez inne media. O artykułach z tygodników opinii 'mówi się' w środowiskach opiniotwórczych" (Podemski, 2011, s. 243).

Powyższa perspektywa analityczna istotnie koresponduje z charakterystyką Tomasza Mielczarka (2013, s. 81), który wymienił trzy uzupełniające się atrybuty prasy opinii: 1 . opiniotwórczy skład zespołu redakcyjnego; 2 . zdominowanie czasopisma przez gatunki publicystyczne; oraz 3. zawartość koncentrującą się na kwestiach społeczno-politycznych i kulturalnych, aczkolwiek z niewielką domieszką treści literackich - zazwyczaj autorstwa osób tożsamościowo bliskich profilowi redakcji.

Przyjmując założenie dotyczące unikalności elitaryzmu symbolicznego tygodników opinii (Podemski, 2011, s. 243), chciałbym wyraźnie zaznaczyć, iż kluczowe jego uzupełnienie stanowi hipoteza, wedle której „dyskurs polityczny odbywający się przy udziale elit symbolicznych wciąż pozostaje w fazie rytualnego chaosu" (Czyżewski i in., 2010; Kotras, 2013). Znaczną część uczestników polskiego dyskursu publicznego charakteryzuje demonstracyjne łamanie i dezawuowanie orientacji przekładalności perspektyw. Oznacza to, że w prowadzonych cyklicznie debatach występuje brak wzmożonej refleksji analitycznej czy też chęci porozumienia z drugą stroną, nie mówiąc już o woli pojednania.

Mamy do czynienia ze stopniową eskalacją sporu w imię zasad moralnej słuszności nad drugą stroną konfliktu. Strony sporu - w tak rozumianej sytuacji nieprzekładalności perspektyw - nie dość, że nie dążą do porozumienia, to nawet zupełny brak możliwości osiągnięcia konsensusu uczyniły istotnym komunikatem dla publiczności (Kotras, 2013, s. 90). Zdaniem Marcina Kotrasa, obserwowany rytualny chaos nie ma charakteru jedynie epizodycznego: „z dużym prawdopodobieństwem można więc przyjąć, że podziały pomiędzy nadawcami medialnymi (w tym przypadku między tytułami prasowymi) odzwierciedlać będą podziały na rynku partyjnym” (Kotras, 2013, s. 107). Badacz wskazuje, że mechanizmy funkcjonowania tygodników opinii przyjmować mogą rolę katalizatorów polaryzacji wśród wyborców dominujących w Polsce ugrupowań, z których każde narzuca własną narrację strategiczną - zazwyczaj wyraźnie antagonistyczną względem przeciwnika.

$\mathrm{Z}$ jednej strony - mamy do czynienia z konkurencyjnymi uniwersami symbolicznymi, których wyrazicielami są elity symboliczne na stałe związane z określonymi tytułami prasowymi. Przykładowo - możemy wyróżnić konserwatywno- 
-liberalne uniwersum symboliczne tygodnika Do Rzeczy (red. nacz. Paweł Lisicki), a także niedaleko umiejscowione od niego pod względem tożsamości - konserwatywno-solidarnościowe uniwersum środowiska tygodnika Sieci (red. nacz. Jacek Karnowski). Analogicznie, dla lewicowej strony polskiej debaty publicznej - możemy przywołać stabilnie osadzone w polskim dyskursie uniwersum symboliczne centrolewicowej Polityki (red. nacz. Jerzy Baczyński), a także kosmopolityczno-lewicowe uniwersum tygodnika Newsweek Polska (red. nacz. Tomasz Lis).

Z drugiej strony - należy przyznać rację Bogusławie Dobek-Ostrowskiej (2011, s. 150), iż wysoce rozwinięty rynek polskiej prasy opiniotwórczej, szczególnie w segmencie tematyki społeczno-politycznej, stanowi dobry przykład pluralizmu zewnętrznego. Znaczna liczba konkurujących ze sobą relewantnych uniwersów symbolicznych umożliwia artykulację rozmaitych (często przeciwstawnych) punktów widzenia i interesów. Tak więc - pomimo całej uzasadnionej krytyki jakości polskiej debaty publicznej - sytuacja na rynku polskich tygodników opinii wpisuje się wprost w proces demokratyczny. Wszak jego warunkiem sine qua non jest wielość dostępnych źródeł informacji i komentarzy dotyczących bieżącego życia publicznego.

\section{Marketing i marketing polityczny - zagadnienia definicyjne}

Definiowanie marketingu politycznego należy rozpocząć od opisania etymologii samego marketingu. Słowo to pochodzi od angielskiego terminu market ('rynek'), ponadto - co intrygujące - nie ma swojego odpowiednika w innych językach. W 1941 roku Amerykańskie Stowarzyszenie Marketingu przedstawiło następującą definicję przedmiotowego pojęcia: „prowadzenie działalności gospodarczej, odnoszącej się do przepływu towarów i usług od producenta do konsumenta lub użytkownika” (Mazur, 2004, s. 15). W latach 60. XX wieku znaczny wkład w rozwój marketingu wniosła koncepcja autorstwa Jerome’a McCarthy’ego, który przedstawił czterofunkcyjny moduł zmiennych zależnych - tzw. marketing mix. Składały się na niego cztery podstawowe elementy charakteryzujące ofertę firmy: cena, produkt, promocja i dystrybucja - tzw. 4P: price, product, promotion, place (Mazur, 2004, s. 14-15).

Kamieniem milowym w rozwoju podejścia marketingowego okazała się teza autorstwa Philipa Kotlera i Sidneya Levy'ego postulująca wieloaspektowość, a także uniwersalny charakter marketingu. Badacze dowodzili, że wiąże się on z szeroko rozumianą, perswazyjną działalnością społeczną, która zdecydowanie może wykraczać poza wąską sferę przemysłowo-handlową. Dla przykładu - zarówno 
w kampaniach politycznych, jak i w procesie rekrutacji na wyższe uczelnie wyjątkowo użyteczna okazuje się orientacja marketingowa. Podejście marketingowe pozwala na wykorzystanie szeregu technik i strategii zarządczych, których celem będzie „urynkowienie” danego produktu (Kotler, Levy, 1969, s. 10).

Philip Kotler postrzega marketing w szerokiej perspektywie, przedstawiając go przede wszystkim jako proces społeczny, którego istota polega na wymianie produktów przez konkretne osoby i grupy (Mazur, 2004, s. 16). Podstawową kategorię marketingu stanowi transakcja - sprowadzająca się do wymiany rozmaitych wartości między dwiema stronami relacji społecznej. Jednakże wartości te nie muszą być ograniczone do fizycznych towarów, usług czy pieniędzy. Mogą to być także inne zasoby, choćby takie jak czas, energia, emocje, idee itp. Ponadto, transakcje zachodzą nie tylko pomiędzy kupującymi i sprzedającymi, ale również pomiędzy jakimikolwiek innymi dwiema stronami (Zajdowski, 2017, s. 43). Od takiego podejścia pozostaje już tylko krok do zagłębienia się w sferę społeczno-politycznych analiz marketingowych.

Nie wszyscy badacze podzielają wieloaspektowe, uniwersalistyczne podejście marketingowe. Przykładowo, Johan Arndt sprowadza rolę marketingu jedynie do aspektów typowo ekonomicznych. Co prawda, zapożyczył od Kotlera koncepcję wymiany (transakcji), jednak w swojej definicji marketingu - jako „procesu społecznego składającego się z koncepcji, planowania i wdrażania całości działań podejmowanych dla wymiany pomiędzy osobami lub zorganizowanymi grupami osób będących aktorami w systemie w celu zaspokojenia potrzeb konsumenta na dobra i usługi ekonomiczne oraz społecznych i środowiskowych efektów tej wymiany" - Arndt zwraca szczególną uwagę na funkcję zaspokajania potrzeb ekonomicznych (Zajdowski, 2017, s. 43-44).

Tytułowa koncepcja marketingu politycznego została wyraźnie zakorzeniona m.in. w teorii wyboru publicznego opracowanej na podstawie teorii racjonalnego wyboru. Leżąca u ich podstaw koncepcja racjonalności zakłada m.in. świadomą i celową maksymalizację indywidualnych korzyści jednostek w ramach dokonywanych przez nie wyborów - bez względu na to, czy będą to decyzje ekonomiczne, społeczne czy też stricte polityczne (Scheffs, 2013, s. 165-168).

W literaturze przedmiotu wyraźnie dostrzegalne są co najmniej dwa nurty definiowania marketingu politycznego: 1) nurt inżynieryjny oraz 2) nurt akcentujący wymiar społeczny zjawiska. Pierwszy z nich traktuje marketing polityczny jako kategorię instrumentalną (graniczącą z podejściem socjotechniczno-propagandowym), służącą - najprościej mówiąc - osiąganiu określonych celów politycznych. Reprezentantką takiego podejścia jest Grażyna Ulicka, dla której marketing polityczny oznacza: „zespół teorii, metod, technik i praktyk społecznych mających na 
celu przekonanie obywateli, by udzielili poparcia człowiekowi, grupie lub projektowi politycznemu". W podejściu drugim marketing polityczny wiąże się ze specyficzną wymianą wartości w warstwie polityczno-społecznej. Jest to perspektywa transakcyjna, kładąca nacisk na społeczne mechanizmy perswazji, a jej reprezentatywnym przedstawicielem jest przywoływany wcześniej Philip Kotler (Scheffs, 2013, s. 170).

Marketing polityczny pod wieloma względami okazuje się zbieżny z mechanizmami marketingu komercyjnego. Świadczy o tym choćby już siatka pojęć stosowana przez specjalistów od marketingu politycznego, którym nieobce są takie kategorie, jak: rynek, segmentacja, targeting, pozycjonowanie produktu, strategie produktowe, branding, rebranding, cykl życia produktu itp. Jednakże występuje wiele cech szczególnych, pozwalających na wyraźne odróżnienie marketingu politycznego (w tym wyborczego) od marketingu komercyjnego sensu stricto. Przede wszystkim - wyborcy zobligowani są do pogodzenia się z wynikami wyborów, nawet w sytuacji, gdy nie są one zgodne z ich preferencjami. Po drugie, bez względu na to, kto wygrywa wybory, wszyscy wyborcy muszą stosować się do ustalanych przez zwycięzców reguł. Po trzecie, partie polityczne i promowani przez nich kandydaci reprezentują kompleksowe całości, dlatego wyborcy de facto nie mają innego wyjścia niż akceptacja albo odrzucenie prezentowanych szyldów w całości. Po czwarte, rynek marketingu politycznego wymaga działalności kolegialnej (często przyjmującej hierarchiczny model sztabowy), opartej przede wszystkim na dobrze zorganizowanej pracy zespołowej, a także - może przede wszystkim - na sprawnym zarządzaniu wizerunkiem partii i kandydatów. Po piąte, należy wskazać, że arena rywalizacji politycznej - w przeciwieństwie do jej wersji komercyjnej-opiera się na retorycznym propagowaniu idei w świecie medialnym oraz prowadzeniu emocjonalnych sporów w ich obronie. Ponadto, marketing polityczny wymaga oparcia logistycznego w strukturach partyjnych lub quasi-partyjnych. Wreszcie należy zaznaczyć, że marketing polityczny w znacznej mierze bazuje na przekazie dyskredytacyjnym wobec adwersarzy, podczas gdy marketing komercyjny w większości przypadków zajmuje się jedynie akredytacją oferowanych produktów (Menon, 2008, s. 6-7).

$\mathrm{Na}$ tym etapie analiz nasuwa się pytanie - czy marketing polityczny można sprowadzić do „kotlerowskiej funkcji transakcyjnej”? Karol Zajdowski dosadnie wskazuje na słabość teorii wymiany w wyjaśnianiu działań marketingowych odnoszących się do świata polityki. Kotlerowska koncepcja wymiany zakłada równorzędność interesów stron transakcji, a także suponuje podobny poziom satysfakcji $\mathrm{z}$ dokonanej wymiany. Tymczasem w przypadku marketingu politycznego trudno mówić o praktycznej realizacji powyższych założeń. Truizmem - z politologiczne- 
go punktu widzenia - wydaje się twierdzenie, że u podstaw zabiegów marketingowych w wykonaniu aktorów politycznych leży zaspokojenie interesów partii lub kandydata (Zajdowski, 2017, s. 47). Marketingowi politycznemu bliżej do jednostronnych prób oddziaływania na odbiorcę ${ }^{2}$, mających na celu wywołanie popytu na promowane produkty - bez względu na ich faktyczną jakość.

Implikuje to, iż pierwotne potrzeby elektoratu pełnią przede wszystkim funkcję elementarnego punktu wyjścia dla późniejszych działań marketingowych. W dalszych etapach właściwie już od wyczucia, kreatywności i jakości sieci kontaktów specjalistów od marketingu zależy sukces kanalizowania uwagi przedstawicieli wybranych segmentów opinii publicznej.

\section{Tygodniki opinii - użyteczny instrument marketingu politycznego?}

Jeżeli za cel komunikowania marketingowego w sferze polityki uznamy wywołanie określonych zachowań (np. oddanie głosu na określonego kandydata w wyborach) lub utworzenie trwałych predyspozycji do przejawiania pożądanych zachowań (np. cyklicznego udzielania poparcia w mediach społecznościowych) - wówczas wszystkie instytucje pośredniczące w wymianie informacji na linii polityk-wyborca mogą pełnić jedną z trzech ról: 1. pomocnika; 2. sprawozdawcy próbującego zachować bezstronność; albo 3. przeciwnika. W tak zarysowanym kontekście należy postawić dwa kluczowe pytania: 1. jakim instrumentarium marketingu politycznego dysponują współcześni politycy oraz ich sztaby?; a także 2. w jakim stopniu mechanizmy funkcjonowania tygodników opinii wpisują się w logikę stosowania powyższego instrumentarium?

Dla potrzeb szerokiego podejścia marketingowego klasyczna kompozycja „4P” autorstwa McCarthy'ego wydaje się niewystarczająca. Stąd formułę „4P” (product, promotion, price, place) należy uzupełnić co najmniej o kolejne „2P” - tj. personnel (kadra) oraz process (proces). Wówczas produktami marketingu politycznego będą wybrane osoby publiczne, grupy takich osób, projekty polityczne lub idee

${ }^{2}$ Kwestię marketingowego sprawowania władzy w jednym ze swoich artykułów naukowych rozważał Mariusz Kolczyński: „Biorąc pod uwagę przekazywane treści i słowa kluczowe: państwo, naród, demokracja, obrona demokratycznego porządku, mamy bez wątpienia do czynienia z propagandą polityczną. Jeżeli przyjrzymy się wyszukanej i nowatorskiej formie, odwołującej się do najlepszych doświadczeń marketingu komercyjnego, skłonni będziemy mówić o marketingu politycznym. Mając na uwadze złożoność oddziaływań medialnych, trudno nie przyznać racji autorom sugerującym daleko idące przemieszanie metod i technik propagandowych i marketingowych, wskutek czego można pokusić się o tezę dotyczącą pojawienia się dychotomicznego zjawiska politycznego: marketingu - propagandy" (por. Kolczyński, 2005, s. 233). 
organizacji życia społecznego. Kategorie te będą podlegały zabiegom promocyjnym, w szczególności poprzez reklamę, kontakt osobisty z elektoratem, kształtowanie wizerunku w ramach public relations oraz promocję uzupełniającą. Cena w omawianym modelu oznacza zarówno ekonomiczny, jak i pozaekonomiczny koszt wyboru kandydata lub opcji politycznej. Dystrybucja polega na efektywnej organizacji kanałów dotarcia do wyborców i odpowiedniej lokalizacji miejsc spotkań. Do personelu marketingowego zaliczać się będą m.in. pracownicy biurowi, wolontariusze i członkowie partii lub organizacji quasi-partyjnej. Tymczasem w ramach działań procesualnych kluczową rolę odgrywają procedury demokratyczne oraz rekrutacja nowych członków (Jaśniok, 2007, s. 85).

Media - ujmowane jako szeroka kategoria instytucji oraz obsługujących je procedur i algorytmów - odpowiadają za obieg informacyjny w nowoczesnym społeczeństwie. Definiują i ustalają hierarchię ważności poszczególnych osób i tematów, realizując funkcję jednego z podstawowych ogniw socjalizacyjnych, propagacyjnych oraz mobilizacyjnych. Wystarczy przywołać koncepcję „spirali milczenia” autorstwa Elisabeth Noelle-Neumann, wedle której środki masowego przekazu - a więc również tygodniki opinii - kreują swoisty klimat emocjonalno-intelektualny dla różnych segmentów opinii publicznej (Kolczyński, 2008, s. 186). Zakładając dorozumianą współpracę określonych mediów z zaprzyjaźnionymi aktorami politycznymi, możliwe staje się kreowanie popytu na rozmaite idee polityczne wśród obywateli/wyborców. Strategiczny mechanizm takich działań polega na sprzężeniu odpowiednich metanarracji politycznych z propagandowymi działaniami podejmowanymi przez media sprzyjające politykom lub całym projektom politycznym. Tacy wpływowi pośrednicy, swoiści brokerzy informacyjno-interpretacyjni, pełniąc rolę dominującą w określonym uniwersum symbolicznym, zyskują moc ustalania hierarchii tematów pojawiających się na agendzie, a także narzucania ich „słusznych” interpretacji.

Jak wskazuje Mariusz Kolczyński, politologiczna analiza użyteczności marketingowej środków społecznego komunikowania o szerokim zasięgu, czyli prasy, radia, telewizji, internetu, a w szerszym znaczeniu nawet książki, filmu, plakatu, kina itp. - odnosi się do wszystkich nadawców medialnych działających w określonej przestrzeni rynku politycznego. Funkcjonowanie tygodników opinii o profilu społeczno-politycznym, co do których przyjąłem założenie unikalności cechującego je elitaryzmu symbolicznego, wpisuje się w koncepcję collective action frames. Zgodnie z jej założeniami, tygodniki opinii poprzez strategiczne kreowanie uniwersów symbolicznych limitują obszar i definiują kwestie będące przedmiotem dyskursu politycznego (Kolczyński, 2008, s. 173-177). Granice tego, co stanowi przedmiot dyskusji w określonej wspólnocie dyskursywnej, mają zazwyczaj cha- 
rakter dorozumiany (wynikający z klimatu ideologicznego, tożsamościowego), a czasami bywają wyraźnie zakreślone poprzez ostre, wewnątrzśrodowiskowe piętnowanie osób głoszących treści nieprawomocne ideologicznie - np. negatywne wobec zaprzyjaźnionego z redakcją polityka.

Twórcy treści medialnych mają władzę kształtowania dyskursu publicznego poprzez odpowiedni dobór słów, obrazów, dźwięków i ich konotacji, tworząc $\mathrm{w}$ ten sposób skojarzenia pewnych zjawisk z odpowiednimi (podświadomymi) reakcjami na te zjawiska - np. stereotypowym odrzuceniem interpersonalnym (Bartoszewicz, 2017, s. 106). Komponent emocjonalny postaw odpowiada za wytwarzanie trwałego stosunku jednostek (wyborców) do określonych polityków. Ponadto, podobne poczucie bliskości może zostać stworzone pomiędzy jednostką a konkretną ideą polityczną - co już samo w sobie stanowi cenny instrument wpływu psychologicznego. Oddziaływania emocjonalne w polityce mają charakter niezwykle skomplikowany: „znaczna część odbiorców ma już ukształtowany stosunek do poszczególnych aktorów politycznych; co więcej, to samo można powiedzieć o odczuciach wobec nadawców medialnych (w ogóle) oraz konkretnych osobistości prezentujących materiały polityczne” (Kolczyński, 2008, s. 188-189).

Katarzyna Brzoza, Dagmara Głuszek-Szafraniec i Patrycja Szostok (2017) - na podstawie autorskich badań empirycznych dotyczących upolitycznienia przekazu prasowego w wybranych polskich tygodnikach opinii - proponują wyszczególnienie modelu traktowania tematyki preferowanych i nielubianych opcji politycznych na łamach różnych redakcji. Otóż, pisząc o opcjach preferowanych, raczej się milczy (omijając niewygodne tematy) lub kreuje przekaz względnie neutralny. Dla „życzliwej krytyki" lub zaakcentowania dystansu wobec pewnych działań służą treści o charakterze mieszanym (np. porównawczym) albo satyrycznym ${ }^{3}$. Inaczej rzecz się ma z tekstami/obrazami dotyczącymi opcji antagonistycznych, o których „pisze się znacznie częściej, krytykując je zarówno wprost, jak i w sposób bardziej zawoalowany, na przykład w tekstach o nacechowaniu ironicznym" (Brzoza i in., 2017, s. 106).

Oprócz opisanego powyżej kreowania tożsamościowych, względnie jednolitych uniwersów symbolicznych, poszczególne elementy funkcjonowania tygodników opinii - analizowane każdy z osobna - wpisują się w logikę działań marketingowych. Jeżeli za produkty marketingu politycznego uznamy wybrane osoby publiczne, grupy takich osób, projekty polityczne lub idee organizacji życia spo-

3 Adekwatny przykład porównawczo-satyrycznej krytyki obecnej na łamach tygodnika Sieci stanowi rubryka „Przegląd tygodnia. Z życia koalicji. Z życia opozycji” autorstwa Roberta Mazurka i Igora Zalewskiego. Por. Sieci (2017), 36, 6-7. 
łecznego - wówczas łamy tygodników opinii stanowią odpowiednie miejsce dla prezentacji sylwetek nowych kandydatów na stanowiska publiczne, którzy dopiero zabiegają o poparcie elektoratu (strategia zdobywania) ${ }^{4}$. Niemniej jednak tygodniki opinii okazują się przydatne również w strategii podtrzymywania poparcia, stosowanej przez kandydatów broniących zajmowanych pozycji - choćby w ramach udzielania wywiadu promowanego na okładce tygodnikas.

Intrygującym przykładem użyteczności marketingowej tygodników opinii będzie organizacja uroczystych gal, w ramach których ogłoszone zostają nominacje na „polityka roku” lub „człowieka wolności”, które to tytuły otrzymują osoby światopoglądowo i środowiskowo bliskie redakcji ${ }^{6}$. Podobny mechanizm występuje przy organizacji rozmaitych wydarzeń kulturalnych przez środowiska tygodników opinii. W ramach dorozumianej współpracy z aktualnie rządzącą grupą polityczną - przebieg tego typu przedsięwzięć może być transmitowany na żywo przez publiczną telewizję; ponadto mogą wziąć w nich udział najwyżsi przedstawiciele państwa polskiego - co przyczynia się do zwiększenia rangi wydarzenia

Zaznaczmy, że do grona współpracowników tygodników opinii niejednokrotnie zaliczają się osoby „reprezentatywne” dla określonych środowisk politycznych. Tytułem przykładu: Tygodnik Sieci współpracuje z Andrzejem Zybertowiczem (Sieci (2017), 34, 128; 40,130) (doradcą społecznym prezydenta Andrzeja Dudy) oraz z Januszem Szewczakiem (Sieci (2017), 38, 82-83) (parlamentarzystą Prawa i Sprawiedliwości). Na łamach Do Rzeczy pojawiają się artykuły autorstwa

${ }^{4}$ Warte przywołania wydaje się akredytacyjne przedstawienie wizerunków kandydatów na stanowisko Prezydenta Warszawy w wykonaniu konkurencyjnych światopoglądowo tygodników opinii: Rafał Trzaskowski (Platforma Obywatelska) na okładce Newsweek Polska (2017) 46; Patryk Jaki (Solidarna Polska) na okładce Sieci (2017), 46.

5 Antoni Macierewicz w wywiadzie i na okładce tygodnika Do Rzeczy (2017), 45; Bronisław Komorowski w wywiadzie i na okładce Polityki (2015) 27.

${ }^{6}$ „Co roku czytelnicy tygodnika Sieci oraz członkowie Kapituły, w skład której wchodzą redaktorzy naczelni i publicyści grupy medialnej Fratria, przyznają tytuł Człowieka Wolności osobie szczególnie zasłużonej w dziele troski o wolną Polskę. W poprzednich latach tytułem tym zostali uhonorowani historyk IPN prof. Krzysztof Szwagrzyk, poeta i pisarz Jarosław Marek Rymkiewicz. W roku 2015 tytuł i statuetkę otrzymał Prezydent Andrzej Duda, a w ubiegłym roku laureatem nagrody został Prezes Prawa i Sprawiedliwości Jarosław Kaczyński”. Zob. https://www.wsieciprawdy.pl/w-poniedzialek-uroczysta-gala-czlowiek-wolnosci-2017-tygodnika-sieci-laureatka-julia-przyl ebska-pnews-3491.html.

7 Tomasz Mielczarek (2013, s. 88) jako ilustrację opisanego zjawiska podaje przykład uroczystości wręczenia dorocznych kulturalnych nagród pisma Polityka w 2011 roku - „w drugiej dekadzie XXI wieku pismo [Polityka - przyp. M.B.] jednoznacznie opowiedziało się za Platformą Obywatelską. Bliskich związków pisma z tą partią polityczną dowodził chociażby fakt, że w $2011 \mathrm{r}$. uroczystość wręczenia dorocznych kulturalnych nagród pisma transmitowała publiczna telewizja, a wzięli w niej udział Prezydent i Premier RP”. 
doradczyni Andrzeja Dudy - Barbary Fedyszak Radziejowskiej (Do Rzeczy (2017), 37, 58-59), a także Zdzisława Krasnodębskiego (europarlamentarzysty Prawa i Sprawiedliwości) (Do Rzeczy (2018), 1, 25-27) oraz Joanny Lichockiej (parlamentarzystki Prawa i Sprawiedliwości) (Do Rzeczy (2018), 11, 42-45; 15, 42-45). Tymczasem tygodnik Polityka cyklicznie publikuje komentarze polityków, m.in. Ludwika Dorna (ministra spraw wewnętrznych i administracji w rządzie Kazimierza Marcinkiewicza) ${ }^{8}$, Leny Kolarskiej-Bobińskiej (ministra nauki i szkolnictwa wyższego w rządzie Ewy Kopacz) ${ }^{9}$ a także Róży Thun (europarlamentarzystki Platformy Obywatelskiej) ${ }^{10}$.

\section{Podsumowanie}

W artykule przyjęto założenie unikalnego elitaryzmu symbolicznego tygodników opinii. Taki status wynika przede wszystkim z jakościowej analizy składu redakcyjnego, do którego wliczają się czołowi przedstawiciele elit symbolicznych dominujących wspólnot dyskursywnych, najlepsi publicyści i komentatorzy, polityczni liderzy, wybitni intelektualiści oraz uznani eksperci (Podemski, 2011, s. 243). Założenie to wymaga jednak istotnego uzupełnienia, iż „dyskurs polityczny odbywający się przy udziale elit symbolicznych wciąż pozostaje $\mathrm{w}$ fazie rytualnego chaosu" (Czyżewski i in., 2010; Kotras, 2013). Mianowicie znaczną część uczestników polskiego dyskursu publicznego charakteryzuje demonstracyjne łamanie i dezawuowanie orientacji przekładalności perspektyw.

W ramach prowadzonych cyklicznie debat, oprócz braku wzmożonej refleksji analitycznej, następuje stopniowa eskalacja sporu w imię zasad moralnej słuszności nad drugą stroną konfliktu. Strony sporu nie dość, że nie dążą do porozumienia, to nawet zupełny brak możliwości osiąnnięcia konsensusu uczyniły istotnym komunikatem dla publiczności. Obserwowany rytualny chaos nie ma jedynie charakteru epizodycznego: „z dużym prawdopodobieństwem można więc przyjąć, że podziały pomiędzy nadawcami medialnymi (w tym przypadku między tytułami prasowymi) odzwierciedlać będą podziały na rynku partyjnym” (Kotras, 2013, s. 107).

Jeżeli za cel komunikowania marketingowego w sferze polityki uznamy wywołanie określonych zachowań stricte wyborczych lub utworzenie trwałych pre-

\footnotetext{
${ }^{8}$ Przykładowe wydania tygodnika Polityka z komentarzami Ludwika Dorna: (2017), 37, 9; 42, 7.

9 Przykładowe wydania tygodnika Polityka z komentarzami Leny Kolarskiej-Bobińskiej: (2017), 39, 8; 44, 9.

${ }^{10}$ Przykładowe wydania tygodnika Polityka z komentarzami Róży Thun: (2017), 40, 8; 43, 9.
} 
dyspozycji do przejawiania pożądanych zachowań - wówczas wszystkie instytucje pośredniczące w wymianie informacji na linii polityk-wyborca mogą pełnić jed ną z trzech ról: 1) pomocnika; 2) sprawozdawcy próbującego zachować bezstronność; albo 3) przeciwnika.

Funkcjonowanie tygodników opinii o profilu społeczno-politycznym wpisuje się w koncepcję collective action frames. Tygodniki opinii, poprzez strategiczne kreowanie uniwersów symbolicznych, limitują obszar i definiują kwestie będące przedmiotem dyskursu politycznego (Kolczyński, 2008, s. 173-177). Granice tego, co stanowi przedmiot dyskusji w określonej wspólnocie dyskursywnej, mają zazwyczaj charakter dorozumiany, związany m.in. z obowiązującym klimatem ideowym. Komponent emocjonalny kreowanych medialnie postaw odpowiada za wytwarzanie trwałego stosunku wyborców do określonych polityków. Podobne poczucie bliskości może zostać stworzone pomiędzy jednostką a konkretną ideą polityczną - co już samo w sobie stanowi cenny instrument oddziaływań socjotechnicznych.

Poszczególne elementy funkcjonowania tygodników opinii - analizowane każdy z osobna - wpisują się w logikę działań marketingowych. Jeżeli za produkty marketingu politycznego uznamy wybrane osoby publiczne, projekty lub idee polityczne - wówczas łamy tygod ników opinii stanowią odpowiednie miejsce dla prezentacji sylwetek nowych kandydatów na stanowiska publiczne. Tygodniki opinii okazują się równie przydatne w strategii podtrzymywania poparcia, stosowanej przez kandydatów broniących zajmowanych pozycji - choćby w ramach udzielania tygodnikowi wywiadu promowanego na okładce. Ponadto, do grona współpracowników rozmaitych tygodników opinii często zaliczają się osoby „reprezentatywne” dla określonych środowisk politycznych, a także aktualni parlamentarzyści lub doradcy najważniejszych przedstawicieli państwa polskiego, co przyczynia się do zmniejszania dystansu tożsamościowego między nimi a określonymi redakcjami.

Współpraca aktorów politycznych z tygodnikami opinii z jednej strony zwiększa ich rozpoznawalność na rynku, jak również pozwala na zaistnienie akredytacyjnego sprzężenia zwrotnego na linii: partie polityczne (wraz z zapleczem) $\rightarrow$ $\rightarrow$ politycy $\rightarrow$ tygodniki opinii $\rightarrow$ stałe grono czytelników/sympatyków/wyborców. Znaczna część osób cyklicznie czytających tygodniki o profilu społeczno-politycznym to lokalni liderzy opinii, nierzadko pełniący rolę środowiskowych przewodników po świecie polityki. Zatem - w perspektywie aktorów zabiegających o akredytację w oczach opinii publicznej - ogromne znaczenie zyskuje możliwość współuczestniczenia w przygotowywaniu zawartości merytorycznej prasy opinii. 


\section{Bibliografia:}

Bartoszewicz, M. (2017). Wybrane aspekty poznawcze i emocjonalne socjotechniki mediów. Studia Medioznawcze, 2(69), 93-106.

Brzoza, K., Głuszek-Szafraniec, D., Szostok, P. (2017). Upolitycznienie przekazu prasowego w wybranych polskich tygodnikach opinii. Wstępny raport z badań. Political Preferences, 16, 81-106, DOI: 10.6084/m9.figshare.5605678.

Czyżewski, M., Kowalski, S., Piotrowski, A. (red.). (2010). Rytualny chaos. Studium dyskursu publicznego. Warszawa: Wydawnictwa Akademickie i Profesjonalne.

Dobek-Ostrowska, B. (2011). Polski system medialny na rozdrożu. Media w polityce, polityka w mediach. Wrocław: Wydawnictwo Uniwersytetu Wrocławskiego.

Jaśniok, M. (2007). Strategie marketingowe na rynku politycznym. Kraków: Wolters Kluwer Polska Sp. z o.o.

Kolczyński, M. (2005). Współczesne komunikowanie polityczne - między propagandą a marketingiem politycznym. Studia Politicae Universitatis Silesiensis, 1, 225-234.

Kolczyński, M. (2008). Strategie komunikowania politycznego. Katowice: Wydawnictwo Uniwersytetu Śląskiego.

Kotler, P., Levy S.J. (1969). Broadening the Concept of Marketing. Journal of Marketing, 33, 10-15.

Kotras, M. (2013). Dwa światy, dwie narracje. Retoryka tygodników opinii „W Sieci” i „Polityka”. Acta Universitatis Lodziensis Folia Sociologica, 46, 89-109.

Mazur, M. (2004). Marketing Polityczny. Studium porównawcze prezydenckich kampanii wyborczych w USA i w Polsce. Warszawa: Wydawnictwo Naukowe PWN.

McQuail, D. (2011). McQuail's Mass Communication Theory: 6th (sixth) Edition. London: SAGE Publications.

Menon, S.V. (2008). Political Marketing: A Conceptual Framework. ICFAI Business School, Ahmadabad.

Mielczarek, T. (2013). Współczesna polska prasa opinii. Rocznik Historii Prasy Polskiej, z. 1(31), 79-102, DOI: 10.2478/yhpp-2013-0015.

Podemski, K. (2011). Świat w polskich tygodnikach opinii. Ruch Prawniczy, Ekonomiczny i Socjologiczny, LXXIII(3), 241-262.

Riedel, R. (2007). Walka o dusze obywateli. Media jako dominujący czynnik socjalizacji politycznej. W: W. Piątkowska-Stepaniak, B. Nierenberg (red.), Wojna w mediach (s. 15-27). Opole: Wydawnictwo Uniwersytetu Opolskiego.

Scheffs, Ł. (2013). Marketing polityczny w ponowoczesnym świecie. Refleksja nad stanem demokracji liberalnej na początku XXI wieku. Świat Idei i Polityki, 12, 164-181.

Zajdowski, K. (2017). Marketing produktu politycznego. Analiza porównawcza. Warszawa: Dom Wydawniczy Elipsa. 